\title{
Sex- and Age-related Changes of Trabecular Bone of Tibia in Growing Domestic Geese (Anser domesticus)
}

\author{
Anna CHARUTA, Małgorzata DZIERZĘCKA, Edward CZERWIŃSKI, Ross Gordon COOPER and \\ Jarosław Olav HORBAŃCZUK
}

Accepted May 22, 2012

\begin{abstract}
Charuta A., DzierzęCKa M., Czerwiński E., CoOper R. G., Horbańczuk J. O. 2012. Sex-and age-related changes of trabecular bone of tibia in growing domestic geese (Anser domesticus). Folia Biologica (Kraków) 60: 205-212.

An analysis of radiological images of the spongious substance of the tibiotarsal bones in domestic goose (120 individuals) was performed for the first time. Based on radiographs obtained from radiological examinations conducted in the region of interest $\left(80 \times 90 \mathrm{~mm}^{2}\right)$ of the proximal metaphysis, an analysis of the spongious substance of the tibia was performed with the Trabecula ${ }^{\circledR}$ programme in order to construct a map of trabeculae and identify their number, volume and density. The results were evaluated statistically using two-way ANOVA. Changes in the number, volume and density of radiological trabeculae of the tibiotarsal bone (TB) in geese from 4 to 16 weeks old were observed. The lowest number $(6.34$ per $\left.\mathrm{mm}^{2}\right)$, volume $(1.50 \% \mathrm{~mm})$ and density $(33.73 \%)$ of radiological trabeculae in the proximal metaphysis of TB was reported in male geese at the age of 6weeks. Similar tendencies were observed in females as well. It should be noted that the volume and density of radiological trabeculae of the tibiotarsal bone achieved a maximum value in males 12 weeks of age, whereas in females at 8 weeks of age. An inverse relationship between body weight and the number of trabeculae in domestic geese $(\mathrm{r}=-0.28 ; \mathrm{P} \leq 0.05)$ was found. We also found a positive relationship between body weight and the volume of radiological trabeculae in domestic geese $(r=0.43 ; \mathrm{P} \leq 0.05)$. During posthatching development, from the 4 th week to slaughter maturity, a decrease in relative bone mass was observed. Negative changes in the trabecular structure combined with high weight gain could lead to bone deformities and locomotor problems in the studied geese.
\end{abstract}

Key words: Bone, geese, tibia, tibiotarsal, Trabecula ${ }^{\circledR}$.

Anna CHARUTA, Vertebrates Morphology Department, University of Natural Sciences and Humanities in Siedlce, Konarskiego 2, 08-110 Siedlce, Poland.

E-mail: anna.charuta@neostrada.pl

Małgorzata DZIERZECKA, Department of Morphological Sciences, Faculty of Veterinary Medicine, University of Life Sciences-SGGW, Nowoursynowska 166, 02-787 Warsaw, Poland. Edward CZERWIŃSKI, Department of Bone and Joint Diseases, Jagiellonian University Medical College, Kopernika 32, in Kraków, 31-501 Kraków, Poland.

Ross Gordon COOPER, 5 Eurohouse, Dog Kennel Lane, Walsall WS1 2BU, England, UK.

Jarosław Olav HORBAŃCZUK, Institute of Genetics and Animal Breeding, Jastrzębiec, Postępu 1,

05-552 Magdalenka, Poland.

Contemporary breeding conditions of birds and their genetic selection in order to achieve a high body weight in the shortest period of time has created higher expectations concerning the mechanical resistance of the skeletal system of birds (FAGAN et al. 2009). A lack of balance in the growth of muscle mass and bones causes frequent deformities and fractures in birds all over the world (FLEMING 2004; HORBAŃCZUK et al. 2004; COOPER et al. 2008; TYKAŁOWSKI et al. 2010). Taking into account the scale of bone pathologies found in geese, it is worthwhile to examine the structure of the bone tissue during posthatching development in these birds.
There are many methods of intravital evaluation of the skeletal system in poultry, such as radiography - the most popular method for bone tissue examination in humans and animals, dual energy X-ray absorptiometry (HESTER et al. 2004), digital fluoroscopy (FLEMING et al. 2004), quantitative computed tomography (TATARA et al. 2004, 2005), as well as microtomography microCT (MARTINEZ-CUMMER 2006). Researchers have been increasingly interested in bone mineralization in poultry. Recent studies provide information on BMD and BMC (BAREIRRO et al. 2009; DZIERZECKA \& CHARUTA 2010; TALATY et al. 2009a, 2009b, 2010). Measurements of bone mineral density in a par- 
ticular bone and posthatching development analysis can predict changes occurring in other parts of the skeleton. This is significant during the in vivo evaluation of the quality of the skeletal system.

Trabecula ${ }^{\circledR}$ is a programme allowing the determination of parameters of bone structure on a radiogram and predicts the resistance of bone tissue. It also allows tracking of the architectural system of trabeculae which plays an important role in shaping the resistance of bone tissue (CZERWIŃSKI 1994). The method is widely used in the diagnostics of fluorine and osteoporotic changes in humans (CZERWIŃSKI 1994), as well as in veterinary medicine to examine the structure of bones in farm animals (DZIERZECKA 2006; DZIERZECCKA et al. 2007; CHARUTA et al. 2008). Trabecula ${ }^{\circledR}$ is a tool allowing the evaluation of bone tissue intravitally, which helps to predict the probability of fractures and deformities of bird bones and helps in applying certain preventive treatments. This method, previously used only in humans, may be useful in diagnostics of young birds which are exposed to limb diseases as well as those which have a high body weight in relation to the developing skeleton.

The aim of the current investigation was to evaluate and determine the changes in the process of shaping the spongious substance in the posthatching development of the tibiotarsal bone of oat geese bred with unlimited access to the yard and a well-balanced diet.

\section{Material and Methods}

The material consisted of radiograms of 120 tibiotarsal bones of White Kołuda Geese (W31). The geese were fed with a standard concentrate (produced by a commercial company Bacutil Bedlno, Poland) and contained $19.5 \%$ protein, $11.72 \mathrm{MJ} / \mathrm{kg}$ at the beginning of fattening and $15.5 \%$ protein and $12.14 \mathrm{MJ} / \mathrm{kg}$ at the end of fattening. The geese were kept for 16 weeks in a free-range system with unlimited access to the yard.

To evaluate the posthatching development of the spongious substance of the tibiotarsal bone in domestic geese, bones were taken from birds in 4-, 6-, 8-, 10-, 12- and 16-weeks of age. The study was conducted on 10 males and 10 females from each age group.

Slaughter and collection of material for research was conducted with the approval of the IIIrd Ethics Committee concerning experiments on animals (Resolution Nr 23/2009). Before slaughter, the animals were weighed and their sex was determined. Then, the tibiotarsal bones were isolated for further analysis. X-rays of the bones were generated with the use of an X-ray apparatus, EDR $750 \mathrm{~B}$, applying radiation of $50 \mathrm{kv}$ and intensity of
$20 \mathrm{~m}$ As. The distance between the lamp and the cassette was $120 \mathrm{~cm}$. Fresh bones were placed directly on the cassette without the use of a diffusion screen. Typical X-ray cassettes by Cawo (Primax Berlin GmbH, Germany) were used. The films were developed in an automatic darkroom (Kodak 35 MX, Frankfurt, Germany). The Trabecula ${ }^{\circledR}$ programme was used to analyse radiological images of the bones (CZERWIŃSKI 1994). Fragments in which the whole bone was visible were scanned. Scanning was performed at a resolution of $300 \mathrm{dpi}$.

The X-ray analysis was conducted in the socalled spongious bone area, where bone trabeculae could clearly be spotted with the naked eye. Images of the spongious substance with the highest diagnostic value were analysed.

A rectangular-shaped fragment $\left(80 \times 90 \mathrm{~mm}^{2}\right)$ of all tibiotarsal bones was matched with the analysis of the structure of the spongious substance. It was extracted below the joint area near the proximal metaphysis. The analysed area did not include the cortical bone. (Fig. 1).

In order to establish which of the parameters are optimal while analysing the structure of the tibiotarsal bones, the number of trabeculae in given horizontal lines on the marked surface of the radiogram was determined by eye. Then the number was compared with the results achieved using the Trabecula ${ }^{\circledR}$ programme which depended on the selection of individual parameters.

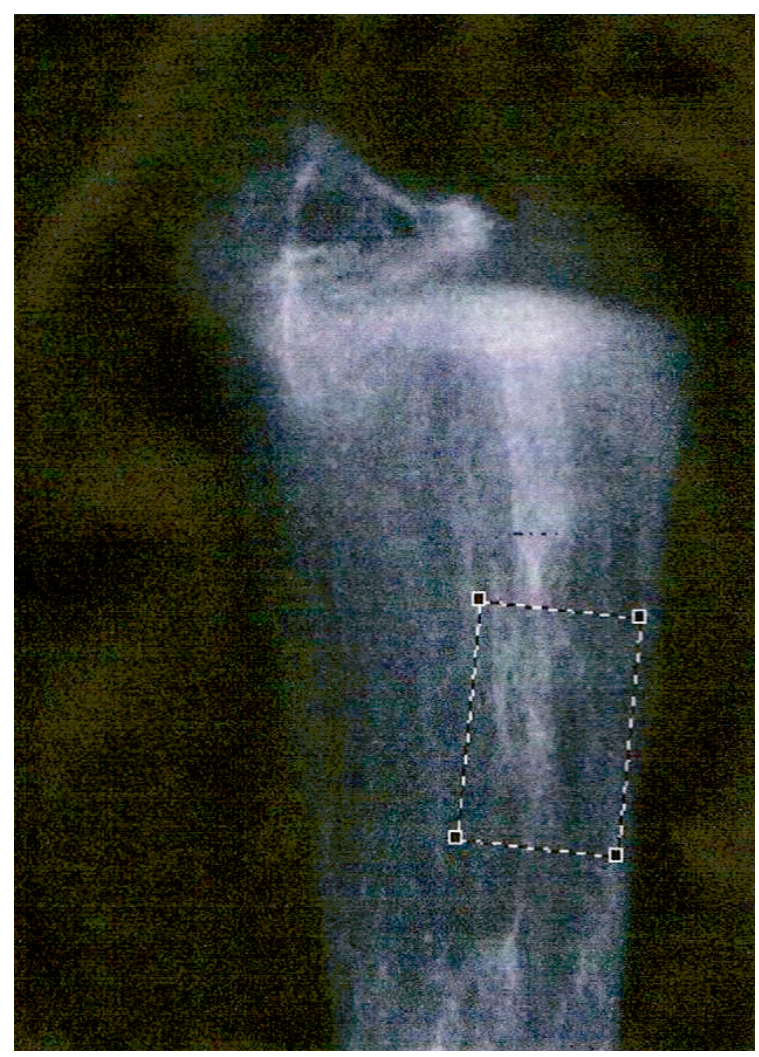

Fig. 1. A fragment of a radiogram of the tibiotarsal bone of a domestic goose with the marked area for analysis $\left(80 \times 90 \mathrm{~mm}^{2}\right)$. 


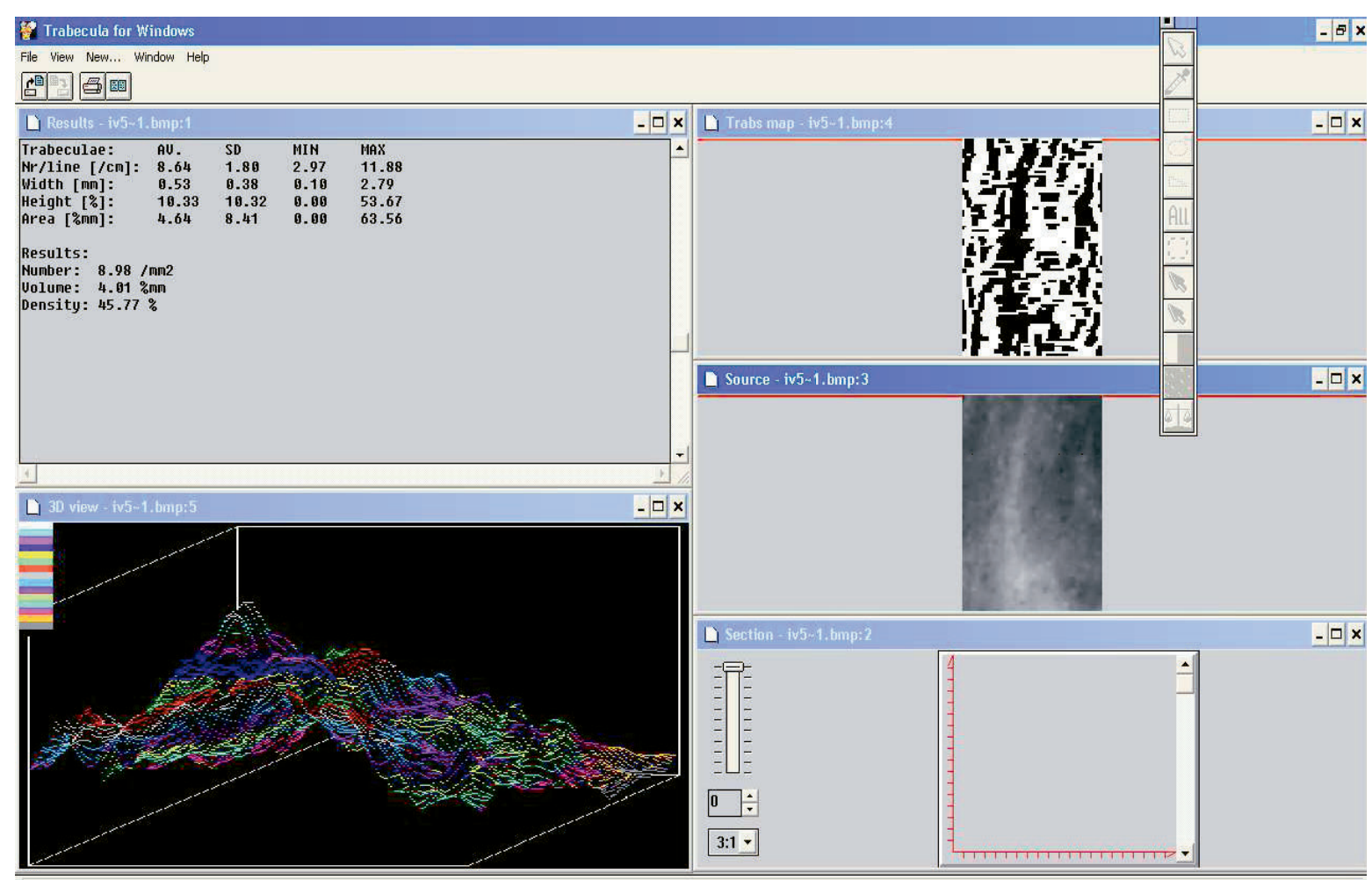

Fig. 2. Computer analysis of the radiological image using the Trabecula ${ }^{\circledR}$ programme.

The Trabecula ${ }^{\circledR}$ programme analysed radiological images recorded at a resolution of $0.096 \mathrm{~mm}$ and showed trabeculae according to a formulated definition. The programme was based on a compatible algorithm of recognising radiological trabeculae: in the form of defined parameters such as the angle and level of the microdensitometer curve. A comparison of the obtained map of trabeculae with the original radiogram revealed that the most credible image was achieved at the following parameters: angle $-20^{\circ}$, level $-40 \%$ and width $200 \%$. The programme recognises a segment of the microdensitometer curve on which it is possible to mark points of the described geometric figure. The figure exists in a quadrilateral shape with an ascending stage, a plateau and a descending stage with defined critical angles.

Having identified trabeculae on subsequent microdensitometer curves, the programme calculated the number of trabeculae, their volume and density. A 128 x 128 matrix recorded digitally was used in the analysis. Trabeculae were recognised as a segment of the curve whose rising and falling angles were $45^{\circ}$. According to this algorithm, the programme analysed 128 curves and made a map of the recognised trabeculae, then it calculated their characteristics for the whole surface as an average from the analysis of the 128 lines.

The programme was used to generate a trabeculae map and imal base measured given in $\% \mathrm{~mm}$ and density given as a percentage of the surface covered with trabeculae for the whole area of the analysis.

\section{Statistical analysis}

The analyses included the following parameters: number, volume and density of radiological trabeculae, body weight as well as tibiotarsal bone weight. Moreover, the relative bone mass (bone weight divided by body weight x $100 \%$ ) was calculated for males and females.

A two-way analysis of variance (variables included sex and age) was conducted in accordance with the model:

$$
\mathrm{y}_{\mathrm{ijl}}=\mathrm{m}+\mathrm{a}_{\mathrm{i}}+\mathrm{b}_{\mathrm{j}}+\mathrm{ab} \mathrm{b}_{\mathrm{ij}}+\mathrm{e}_{\mathrm{ijl}} \text {. }
$$

where: $y_{i j}-$ value of the studied feature, $m$ - population average, $\mathrm{a}_{\mathrm{i}}-\mathrm{i}$ - effect of the level of $\mathrm{A}$ factor, $b_{j}-j-$ effect of the level of B factor, $a b_{i j}$ - effect of interaction between $\mathrm{i}$ and $\mathrm{j}, \mathrm{e}_{\mathrm{ijl}}$ - random error.

To define the differences in the studied quantitative features, which could be influenced by sex, the results were analysed separately for males and females.

Standard deviations $( \pm \mathrm{SD})$ and arithmetical means $(\bar{x})$ were calculated. Differences between the mean values were determined with Tukey's test, at $\mathrm{P} \leq 0.05$. 
The relationship between body weight and the number of analysed radiological trabeculae as well as their volume, density and width were examined using coefficients of correlation and regression at $\mathrm{P} \leq 0.05$.

\section{Results}

The obtained results are shown in Table 1:

The mean number of radiological trabeculae in the spongious bone of the proximal metaphysis in 4 -wk-old geese both in males and females was similar $-9.6 \mathrm{~mm}^{2}$, whereas in 6-wk-old male $\left(6.34 \mathrm{~mm}^{2}\right)$ and females $\left(7.67 \mathrm{~mm}^{2}\right)$ was the lowest. (Table 1).
The highest growth rate of body weight in geese during the posthatching period occurred between 4 and 6 weeks of age $-1400 \mathrm{~g}$, whereas bone weight increased only by $10 \mathrm{~g}$ (Table 2 ). However, irrespective of the high increase in bone weight between the $4^{\text {th }}$ and $6^{\text {th }}$ week, the relative bone weight decreased from $1.0 \%$ to $0.9 \%$. Thus, body weight grew much faster than bone mass. It is worth emphasising that from 8 weeks to 16 weeks, there was a decrease both in bone weight (from $34.58 \mathrm{~g}$ to $29.83 \mathrm{~g}$, at $\mathrm{P} \leq 0.05$ ) and in relative bone weight (from $0.8 \%$ in 4 wk to $0.5 \%$ in $6 \mathrm{wk}$, at $\mathrm{P} \leq 0.05$ ) but the body weight constantly grew (Table 2). From among the 6 analysed developmental stages, 4-week geese of both sexes presented the highest relative bone weight, approx. $1 \%$. In the $16^{\text {th }}$ week,

Table 1

Average values $(\bar{x})$ and standard deviation $\pm \mathrm{SD}$ of the number, volume and density of radiological trabeculae of the tibiotarsal bones of oat geese as influenced by age $(4,6,8,10$, 12 or $16 \mathrm{wk}$ ) sex and body weight

\begin{tabular}{|c|c|c|c|}
\hline Item & Males $( \pm \mathrm{SD})$ & Females $( \pm \mathrm{SD})$ & Species average $( \pm \mathrm{SD})$ \\
\hline \multicolumn{4}{|c|}{ Number $\left(\mathrm{mm}^{2}\right)$} \\
\hline $4 \mathrm{wk}$ & $9.69 \mathrm{~b}, \mathrm{~B} \pm 1.00$ & $9.46 \mathrm{a} \pm 1.17$ & $9.60 \mathrm{c}, \mathrm{C} \pm 1.02$ \\
\hline $6 \mathrm{wk}$ & $6.34 \mathrm{a}, \mathrm{A}^{* * \pm 1.26}$ & $7.67 \mathrm{a}^{* *} \pm 1.88$ & $7.22 \mathrm{a}, \mathrm{A} \pm 1.76$ \\
\hline $8 \mathrm{wk}$ & $9.02 \mathrm{~b}, \mathrm{~B} \pm 0.90$ & $9.96 \mathrm{a} \pm 0.15$ & $9.49 \mathrm{~b}, \mathrm{~B}, \mathrm{c}, \mathrm{C} \pm 0.12$ \\
\hline $10 \mathrm{wk}$ & $8.39 b \pm 0.41$ & $7.95 \mathrm{a} \pm 1.20$ & $8.17 \mathrm{a}, \mathrm{A}, \mathrm{b}, \mathrm{B} \pm 0.86$ \\
\hline $12 \mathrm{wk}$ & $9.60 \mathrm{~b}^{* *} \pm 0.57$ & $7.89 \mathrm{a} * * \pm 0.73$ & $8.08 \mathrm{a} \pm 0.89$ \\
\hline $16 \mathrm{wk}$ & $8.45 \mathrm{~b}, \mathrm{~B} \pm 0.76$ & $7.83 \mathrm{a} \pm 0.69$ & $7.96 \mathrm{a} \pm 0.72$ \\
\hline \multicolumn{4}{|c|}{ Volume $(\% \mathrm{~mm})$} \\
\hline $4 \mathrm{wk}$ & $1.63 \mathrm{a} \pm 0.16$ & $1.23 \mathrm{a}, \mathrm{b} \pm 0.41$ & $1.48 \mathrm{a} \pm 0.33$ \\
\hline $6 \mathrm{wk}$ & $1.50 \mathrm{a}, \mathrm{A} \pm 0.55$ & $1.71 \mathrm{a}, \mathrm{b} \pm 0.48$ & $1.64 \mathrm{a} \pm 0.48$ \\
\hline $8 \mathrm{wk}$ & $2.38 \mathrm{a}, \mathrm{b} \pm 0.43$ & $2.80 \mathrm{~b} \pm 0.38$ & $2.60 \mathrm{c} \pm 0.44$ \\
\hline $10 \mathrm{wk}$ & $2.33 \mathrm{a}, \mathrm{b} \pm 0.44$ & $2.36 \mathrm{a}, \mathrm{b} \pm 0.47$ & $2.35 \mathrm{~b}, \mathrm{c} \pm 0.42$ \\
\hline $12 \mathrm{wk}$ & $3.03 \mathrm{~b}, \mathrm{~B} \pm 0.32$ & $2.33 \mathrm{a}, \mathrm{b} \pm 0.38$ & $2.41 \mathrm{c} \pm 0.42$ \\
\hline $16 \mathrm{wk}$ & $1.81 \mathrm{a} \pm 0.14$ & $1.78 \mathrm{a} \pm 0.51$ & $1.80 \mathrm{a}, \mathrm{b} \pm 0.45$ \\
\hline \multicolumn{4}{|l|}{ Density $(\%)$} \\
\hline $4 \mathrm{wk}$ & $44.16 \mathrm{~b}, \mathrm{~B} \pm 2.17$ & $41.65 \mathrm{~b} \pm 3.19$ & $43.19 a, b \pm 2.78$ \\
\hline $6 \mathrm{wk}$ & $33.73 \mathrm{a}, \mathrm{A}^{* *} \pm 2.82$ & $37.97 \mathrm{a}^{* *} \pm 2.26$ & $36.55 \mathrm{a} \pm 5.32$ \\
\hline $8 \mathrm{wk}$ & $43.56 \mathrm{~b} \pm 2.47$ & $45.83 \mathrm{~b} \pm 0.27$ & $44.69 \mathrm{~b} \pm 2.05$ \\
\hline $10 \mathrm{wk}$ & $41.45 \mathrm{~b} \pm 1.18$ & $40.66 \mathrm{~b} \pm 4.33$ & $41.05 \mathrm{a}, \mathrm{b} \pm 2.97$ \\
\hline $12 \mathrm{wk}$ & $46.37 b^{*} \pm 0.94$ & $41.33 b^{*} \pm 1.52$ & $41.89 \mathrm{a}, \mathrm{b} \pm 2.19$ \\
\hline $16 \mathrm{wk}$ & $40.44 b^{* *} \pm 1.7$ & $36.51 \mathrm{a}^{* *} \pm 11.45$ & $37.35 \mathrm{a} \pm 10.2$ \\
\hline \multicolumn{4}{|c|}{ Body weight $(\mathrm{g})$} \\
\hline $4 \mathrm{wk}$ & $2362 \mathrm{a}, \mathrm{A} \pm 206$ & $1960 \mathrm{a} \pm 343$ & $2207 \mathrm{a} \pm 325$ \\
\hline $6 \mathrm{wk}$ & $3760 \mathrm{~b}, \mathrm{~B} \pm 531$ & $3370 b \pm 270$ & $3500 b \pm 400$ \\
\hline $8 \mathrm{wk}$ & $4233 \mathrm{c}, \mathrm{C} \pm 136$ & $3790 \mathrm{c} \pm 162$ & $4011 \mathrm{c} \pm 272$ \\
\hline $10 \mathrm{wk}$ & $4915 \mathrm{~d}, \mathrm{D} \pm 427$ & $4340 \mathrm{~d} \pm 193$ & $4627 \mathrm{~d} \pm 434$ \\
\hline $12 \mathrm{wk}$ & $5450 \mathrm{~d}, \mathrm{e}, \mathrm{D}, \mathrm{E} \pm 98$ & $4693 \mathrm{~d}, \mathrm{e} \pm 82.1$ & $4777 \mathrm{~d}, \mathrm{e} \pm 263$ \\
\hline $16 \mathrm{wk}$ & $5600 \mathrm{e} \pm 200$ & $4854 \mathrm{e} \pm 182$ & $5014 \mathrm{e} \pm 364$ \\
\hline
\end{tabular}

a,b...,e Means within a column with different superscripts are significantly different $(\mathrm{P} \leq 0.05)$.

A,B ...,E Means within a column with different superscripts are significantly different $(\mathrm{P} \leq 0.01)$.

$*$ Means within a row are significantly different $(\mathrm{P} \leq 0.05)$.

**Means within a row are significantly different $(\mathrm{P} \leq 0.01)$. 
Table 2

Mean values $(\overline{\mathrm{x}})$ and standard deviation $\pm \mathrm{SD}$ of the bone length, bone weight, body weight and relative bone weight of tibiotarsal bones of domestic geese as influenced by age $(4,6,8$, 10,12 or 16 week) and sex

\begin{tabular}{|c|c|c|c|}
\hline Item & Males $( \pm \mathrm{SD})$ & Females $( \pm \mathrm{SD})$ & Pooled sexes $( \pm \mathrm{SD})$ \\
\hline \multicolumn{4}{|c|}{ Bone length (mm) } \\
\hline $4 \mathrm{wk}$ & $143.53^{a} \pm 0.04$ & $143.77^{\mathrm{a}} \pm 0.45$ & $143.77^{\mathrm{a}} \pm 0.31$ \\
\hline $6 \mathrm{wk}$ & $171.05^{\mathrm{b}} *_{ \pm} 0.59$ & $158.30^{\mathrm{b} *} \pm 0.54$ & $158.30^{\mathrm{b}} \pm 0.82$ \\
\hline $8 \mathrm{wk}$ & $171.84^{\mathrm{b} * \pm 0.23}$ & $160.22^{\mathrm{b} *} \pm 0.35$ & $160.22^{\mathrm{b}} \pm 0.67$ \\
\hline $10 \mathrm{wk}$ & $176.56^{\mathrm{c} *} \pm 0.90$ & $167.12^{\mathrm{c} *} \pm 0.87$ & $167.12^{\mathrm{c}} \pm 0.97$ \\
\hline $12 \mathrm{wk}$ & $177.73^{c} \pm 0.65$ & $171.35^{\mathrm{c}} \pm 0.70$ & $171.35^{\mathrm{c}} \pm 0.72$ \\
\hline $16 \mathrm{wk}$ & $180.88^{\mathrm{c}} * \pm 0.41$ & $171.94^{\mathrm{c} *} \pm 0.30$ & $171.94^{\mathrm{c}} \pm 0.57$ \\
\hline \multicolumn{4}{|c|}{ Tibiotarsal bone weight (g) } \\
\hline $4 \mathrm{wk}$ & $24.46^{\mathrm{a}} \pm 0.80$ & $24.21^{\mathrm{a}} \pm 2.13$ & $24.34^{\mathrm{a}} \pm 1.54$ \\
\hline $6 \mathrm{wk}$ & $34.06^{\mathrm{b} *} \pm 1.16$ & $32.08^{\mathrm{b} * \pm 1.92}$ & $33.07^{b} \pm 1.84$ \\
\hline $8 \mathrm{wk}$ & $34.58^{\mathrm{b}} \pm 1.16$ & $33.38^{\mathrm{b}} \pm 0.87$ & $33.93^{\mathrm{b}} \pm 1.14$ \\
\hline $10 \mathrm{wk}$ & $31.70^{\mathrm{b}} \pm 2.00$ & $29.52^{c} \pm 0.57$ & $30.97^{c} \pm 1.94$ \\
\hline $12 \mathrm{wk}$ & $30.10^{\mathrm{c}} \pm 0.52$ & $29.44^{\mathrm{c}} \pm 0.32$ & $29.70^{\mathrm{c}} \pm 0.51$ \\
\hline $16 \mathrm{wk}$ & $29.83^{c} * \pm 0.47$ & $29.36^{\mathrm{c} *} \pm 0.86$ & $29.57^{c} \pm 0.72$ \\
\hline \multicolumn{4}{|c|}{ Body weight $(\mathrm{g})$} \\
\hline $4 \mathrm{wk}$ & $2362^{a} \pm 206$ & $1960^{a} \pm 343$ & $2207^{a} \pm 325$ \\
\hline $6 \mathrm{wk}$ & $3760^{b} \pm 531$ & $3370^{b} \pm 270$ & $3500^{b} \pm 400$ \\
\hline $8 \mathrm{wk}$ & $4233^{c} \pm 136$ & $3790^{c} \pm 152$ & $4011^{c} \pm 272$ \\
\hline $10 \mathrm{wk}$ & $4915^{d} \pm 427$ & $4340^{d} \pm 193$ & $4627^{d} \pm 434$ \\
\hline $12 \mathrm{wk}$ & $5450^{\mathrm{d}, \mathrm{e}} \pm 98$ & $4693^{\mathrm{d}, \mathrm{e}} \pm 82.1$ & $4777^{\mathrm{d}, \mathrm{e}} \pm 263$ \\
\hline $16 \mathrm{wk}$ & $5450^{\mathrm{e}} \pm 200$ & $4854^{\mathrm{e}} \pm 182$ & $5014^{\mathrm{e}} \pm 364$ \\
\hline \multicolumn{4}{|c|}{ Relative bone mass (\%) } \\
\hline $4 \mathrm{wk}$ & $1.0^{\mathrm{a}} \pm 0.0$ & $1.2^{\mathrm{a}} \pm 0.0$ & $1.1^{\mathrm{a}} \pm 0.0$ \\
\hline $6 \mathrm{wk}$ & $0.9^{\mathrm{a}} \pm 0.00$ & $1.0^{\mathrm{a}} \pm 0.0$ & $0.9^{\mathrm{a}} \pm 0.0$ \\
\hline $8 \mathrm{wk}$ & $0.8^{\mathrm{a}} \pm 0.0$ & $0.9^{\mathrm{a}} \pm 0.0$ & $0.9^{\mathrm{a}} \pm 0.0$ \\
\hline $10 \mathrm{wk}$ & $0.6^{\mathrm{b}} \pm 0.0$ & $0.7^{\mathrm{b}} \pm 0.0$ & $0.7^{\mathrm{b}} \pm 0.0$ \\
\hline $12 \mathrm{wk}$ & $0.6^{\mathrm{b}} \pm 0.0$ & $0.6^{\mathrm{b}} \pm 0.0$ & $0.6^{\mathrm{b}} \pm 0.0$ \\
\hline $16 \mathrm{wk}$ & $0.5^{b} \pm 0.0$ & $0.6^{\mathrm{b}} \pm 0.0$ & $0.6^{\mathrm{b}} \pm 0.0$ \\
\hline
\end{tabular}

${ }^{a, b \ldots, e}$ Means within a column with different superscripts are significantly different $(\mathrm{P} \leq 0.05)$.

*Means within a row are significantly different $(\mathrm{P} \leq 0.05)$.

on the other hand, the relative bone weight was only $0.5 \%$ (Table 2 ).

It should be emphasised that deformities occurred most frequently (around $20 \%$ in females and $40 \%$ in males) in 6-week-old geese. At this period of bone growth, a higher incidence of health problems connected with locomotory function was observed in geese. Moreover, a higher relation of the body weight to bones leads to extensive loading and bone deformities including fractures of the tibiotarsal bone (Fig. 3).

In 6-week-old domestic geese the number of radiological trabeculae significantly correlated with sex, whereas in males, the number depended on age, as well. The correlation between the number of trabeculae and the body weight of domestic geese $(\mathrm{r}=-0.28 ; \mathrm{P} \leq 0.05)$ proved that there was a relationship between these two features. The regression equation showed that when body weight increased by $1 \mathrm{~g}$, the number of trabeculae dropped by $0.000364 \mathrm{~mm}^{2}$ (Table 3).

The number of trabeculae increased in 8-weekold geese, both in males and females, and reached approximately $9.02 \mathrm{~mm}^{2}$ and $9.96 \mathrm{~mm}^{2}$, respectively. It should be noted that the number of trabeculae decreased among geese of both sexes and between 12 and 16 weeks of age is lower than in 4 week old geese (Table 1).

Another studied parameter was the volume of radiological trabeculae of the tibiotarsal bone. The 


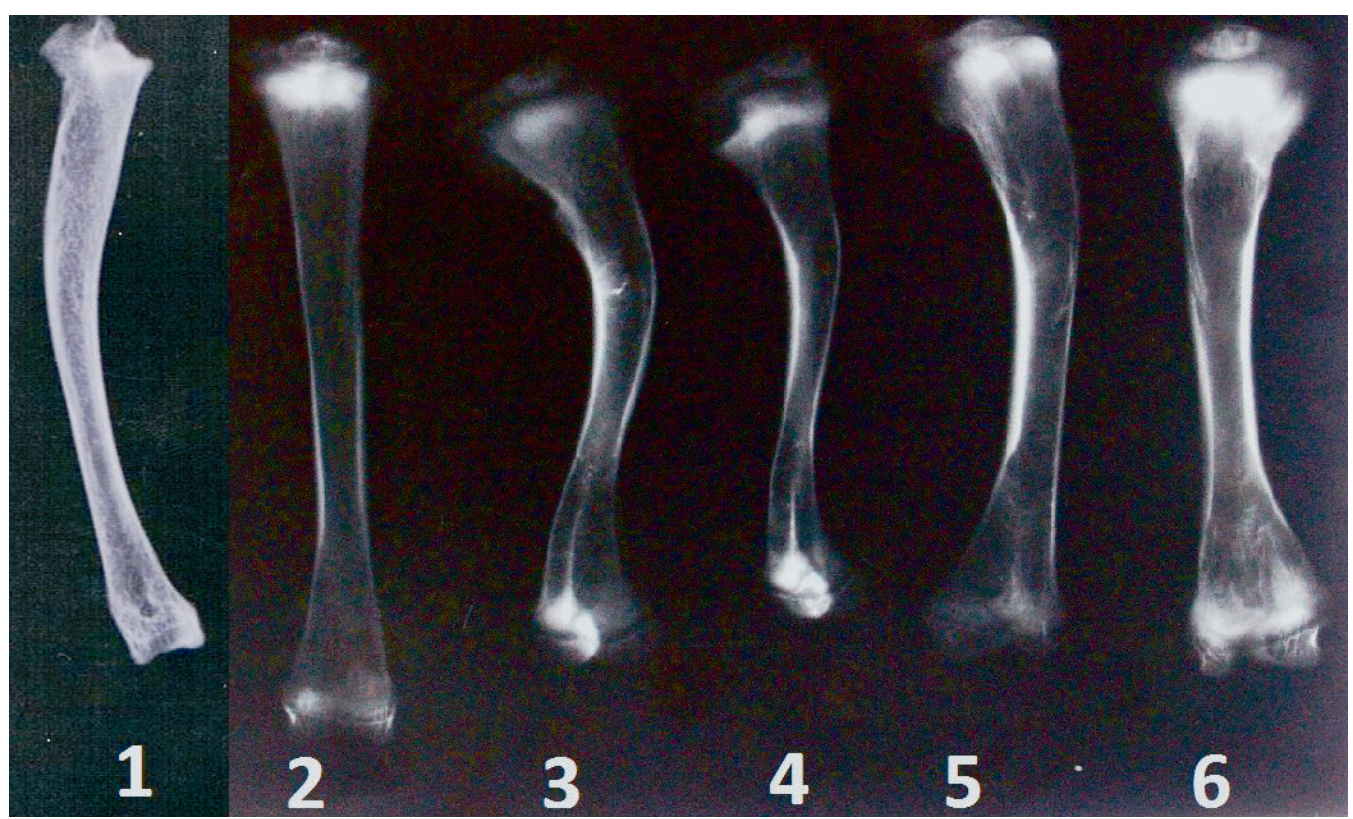

Fig. 3. Various forms of deformities of tibiotarsal bone in 6-week domestic geese. 1 - bowed bone of 6-week male; 2 -properly built tibiotarsal bone of 6-week male; 3, 4,5-deformations of the proximal metaphysis and the middle of the bone of 6-week males; 6 - deformed tibial bone of 6 -week female domestic geese. Visible enlargements in epiphyses and metaphyses.

Table 3

Values of correlation coefficients between the studied features (body weight, number, volume and density of trabeculae ) in domestic geese

\begin{tabular}{||l|c|c||}
\hline \multirow{2}{*}{\multicolumn{1}{|c|}{ Studied feature }} & \multicolumn{2}{c||}{ domestic geese } \\
\cline { 2 - 3 } & Correlation coefficient & Regression equation \\
\hline Body weight $x$ number of trabeculae & $-0.28^{*}$ & $\mathrm{Y}=9.895-0.000364 \mathrm{x}$ \\
\hline Body weight $\mathrm{x}$ volume of trabeculae & $0.43^{*}$ & $\mathrm{Y}=1.004+0.000250 \mathrm{x}$ \\
\hline Body weight $\mathrm{x}$ density of trabeculae & -0.08 & \\
\hline
\end{tabular}

*significant at $\mathrm{P} \leq 0.05$

Explanation:

In domestic geese a negative relationship between the body weight and the number of trabeculae was observed. The regression equation shows that when the body weight increases by $1 \mathrm{~g}$, the number of trabeculae falls by $0.000364 \mathrm{~mm}^{2}$.

There is also a relationship between the body weight and the volume of radiological trabeculae in domestic geese. If the body weight increases by $1 \mathrm{~g}$, the volume rises by $0.000250 \% \mathrm{~mm}$.

The relationships between the body weight of domestic geese and the density of radiological trabeculae were not recorded

maximum value of this feature was achieved in males at 12 weeks of age, whereas in females at 8 weeks of age. In turn, the average density of trabeculae in the proximal metaphysis was the lowest in 6-week-old males and amounted to $33.73 \%$. Significant differences between males and females $(\mathrm{P} \leq 0.05)$ were found in this parameter (Table 1).

The correlation between the volume of trabeculae and the body weight of domestic geese was $r=$ $0.43 ; \mathrm{P} \leq 0.05$. When the body weight was bigger, the volume of trabeculae increased as well (Table 3 ).
The regression coefficient indicates that when the body weight increases by $1 \mathrm{~g}$, the volume of trabeculae increases by $0.000250 \% \mathrm{~mm}$ (Table 3 ).

\section{Discussion}

Selecting the tibiotarsal bone as a model for research is justified as its proximal metaphysis contains large amounts of spongious substance in which metabolic processes are the most intense. 
Therefore, pathological changes, e.g. symptoms of decreased bone density, are visible in the spongious substance quite early. Tibiotarsal bone in fast growing poultry is prone to disorders of the mineralisation process. The disorders in the spongious bone of the tibial metaphyses lead to bone deformities and fractures.

The deformities and fractures of TT bones and mineralisation disorders were recorded among meat type birds (turkeys, ducks, geese, chickens) (TYKAŁOWSKI et al. 2010). In slaughter turkeys, the deformities and disorders of mineralisation were caused by tibial dyschondroplasia and occurred in the cartilage of the proximal tibial epiphysis (POULOS et al. 1978; LYNCH et al. 1992; PETERS et al. 2002). Very often, tibial deformities in poultry were caused by decreased blood supply in bones (SIMSA et al. 2007), exceedingly fast growth (WILLIAMS et al. 2003) and vitamin deficiency - rickets (HUFF et al. 1999). Calcium and phosphorus deficiencies in the plasma were also the cause of rickets (BAR et al. 1987). Moreover, bones of birds kept in cages were more prone to fractures (JEDRAL et al. 2008). The deformities of long bones in poultry can result in a decline of production efficiency. Taking into consideration the range of pathologies, the following research was performed to examine the changes in the structure of spongious substance of the TT bone in domestic goose. With the help of the Trabecula ${ }^{\circledR}$ programme, it was recorded that in posthatching development, the lowest number and the lowest density of trabeculae were observed among 6-week-old geese, both males and females. At this age, the highest number of locomotor function disorders connected with deformation of tibia was reported (bow-shaped bones) .

Similar results were obtained on ducks by CHARUTA et al. 2011, in which (for both sexes) the lowest number of radiological trabeculae per 1 $\mathrm{mm}^{2}$ in the area of spongious bone of the proximal metaphysis was also reported at the age of 6 weeks and amounted to $10.34 \mathrm{~mm}^{2}$.

On the basis of analysis of the bone tissue structure with the use of the Trabecula ${ }^{\circledR}$ programme, significant statistical differences between age groups of domestic geese were observed. At the age of 16 weeks, when the birds become sexually mature, the volume of trabeculae of the proximal metaphysis declines significantly in comparison with younger birds. Analysing the sex groups, no statistically significant differences concerning the volume of trabeculae between males and females were observed for a particular age. The volume of trabeculae depended only on age and was independent of sex. CHARUTA et al. (2011) reported that there were significant differences in the volume of radiological trabeculae depending on sex in 6-week-old ducks.
The average density of trabeculae as a percentage of a cube with the maximal and minimal base measured, given in $\% \mathrm{~mm}$, in the proximal metaphysis was the lowest in 6 -week-old males and amounted only to $33.73 \%$. The density of radiological trabeculae of the birds showed significant differences between males and females. In research conducted by CHARUTA et al. (2011), it was reported that among ducks the lowest density, expressed as a percentage of the surface covered with trabeculae for the whole area of the analysis, was characteristic for females and amounted to $44.62 \%$. On the basis of the conducted analysis, it was found that there are significant differences between sexes in the density of trabeculae in the proximal metaphysis of 6- and 16-week-old domestic geese. Density values depend on the age group and sex.

Similar results were observed in ducks in studies performed by CHARUTA et al. (2011). The density of trabeculae in 6-week-old ducks was the lowest as well. Macroscopic deformities of the tibiotarsal bones in 6-week-old males and females can be explained by the microscopic structure of the proximal metaphysis of the tibiotarsal bone. At that age, both the number of trabeculae and their density are the lowest in males and females. A relationship between body weight and density was not detected.

Research concerning changes in the density of poultry bones as influenced by age and sex was conducted by TALATY et al. (2009a, 2010). The authors analysed changes in mineralisation of the humeral and tibial bones in broiler chickens of both sexes from the second to the eighth week of life using dual energy X-ray absorptometry (DEXA). Mineral density was the largest in 4-week-old broiler chickens and slightly bigger in cocks (TALATY et al. 2009a). In domestic geese the highest density in situ was observed in the proximal metaphysis in 12-week-old males and 8-week-old females.

In conclusion the lowest number $\left(6.34 \mathrm{~mm}^{2}\right)$, volume $(1.50 \% \mathrm{~mm})$ and density $(33.73 \%)$ of radiological trabeculae in the proximal metaphysis of the tibiotarsal bone was reported at the age of 6 weeks in males of the domestic goose. This may be associated with fractures and deformities of the tibiotarsal bones occurring mainly in 6-week-old males $(40 \%)$.

The current research showed that the adaptation of the Trabecula ${ }^{\circledR}$ programme is useful for studying bone morphology at the microstructural level in birds, for example, the structure of the spongious substance of the tibiotarsal bone in the posthatching development of domestic geese. Applying this non-invasive method in orthopaedic diagnostics in birds is very useful because it allows the recognition of disorders in the spongious substance of birds. 


\section{References}

Bar A., Rosenberg J., Perlman R., Hurwitz S. 1987. Field rickets in turkeys: relationship to vitamin D. Poult. Sci. 66: $68-72$.

Barreiro F. R., Sagula A. L,. Junqueira O. M., Pereira G. T., BARALDI-ARTONI S. M. 2009. Densitometric and biochemical values of broiler tibias at different ages. Poult. Sci. 88: $2644-2648$

CHARUTA A, MajChrZAK T, CZERWińSKi E, COOPER R. G. 2008. Spongious matrix of the tibiotarsal bone of ostriches (Struthio camelus) - a digital analysis. Bull. Vet. Inst. Pulawy, 52: 175-178.

Charuta A., DZIERZECKA M., MajchrzaK T., CZERwiŃSKI E., COOPER R. G. 2011. Computer-generated radiological imagery of the structure of the spongious substance in the postnatal development of the tibiotarsal bones of the Peking domestic duck (Anas platyrhynchos var. domestica). Poult. Sci. 90: 830-835.

CoOper R. G., NARAnOwicz H., Maliszewska E., TenNETT A., HORBAŃCZUK J. O. 2008. Sex- based comparison of limb segmentation in ostriches aged 14 months with and without tibiotarsal rotation. J. South African Vet. Assoc. 7 142-144.

CZERWIŃSKI E. 1994. A quantitative measurement of changes appearing under the influence of fluoride in cortical and orbicular bone. Habilitation dissertation, Collegium Medicum UJ, Kraków. Poland. (In Polish).

DZIERZECKA M., CHARUTA A. 2006. Modern methods in the evaluation of bone tissue quality and possibility of their application in veterinary medicine. Medycyna Wet. 62 : 617-620. (In Polish)

DZIERZECKA M., CHARUTA A. 2010. The bone mineral density (BMD) and content (BMC) of the skeleton of the thoracic and the pelvic limb in the ostrich (Struthio camelus var. domesticus) as influenced by sex. Bull. Vet. Inst. Pulawy. 54: 601-604.

DZIERZECKA M., MAJCHRZAK T., CZERWIŃSKi E,. KOBRYŃ H. 2007. Digital assessment of radiograms of the spongy structure of the proximal phalanx of thoroughbreds and Arabian horses. Medycyna Wet. 63: 1443-1447. (In Polish).

Fagan A. B., Kennaway D. J., OAKley A. P. 2009. Pinealectomy in the chicken: a good model of scoliosis. Eur. Spine J. 18: 1154-1159.

Fleming R. H., Korver D., MCCORMACK H. A., WhiteHEAD C. C. 2004. Assessing bone mineral density in vivo: digitized fluoroscopy and ultrasound. Poult. Sci. 83: 207-214.

Hester P. Y., Schreiweis M. A., Orban J. I., MaZZuCO H., KOPKA M. N., LEDUR M. C., MOODY D. E. 2004. Assessing bone mineral density in vivo: Dual Energy X-ray Absorptiometry. Poult. Sci. 83: 215-221.
HORBAŃCZUK J. O, HUCHZERMEYER F., PARADA R, PŁAZA K. 2004. Four-legged ostrich (Struthio camelus) chick. Vet. Rec. 154: 736.

Huff W. E., Huff G. R., Clark F. D., Moore Jr. P. A., RATH N. C., BALOG J. M, BARNES D. M. ERF G. F., BEERS K. W. 1999. Research on the probable cause of an outbreak of field rickets in turkeys. Poult. Sci 78: 1699-1702.

JENDRAL M. J., Korver D. R., CHURCH J. S., FEDDES J. J. R. 2008. Bone mineral density and breaking strength of white leghorns housed in conventional, modified, and commercially available colony battery cages. Poult. Sci. 87: 828837.

LYNCH M., THORP B., WhITEHEAD C. 1992. Avian tibia dyschondroplasia as a cause of bone deformity. Avian Pathol. 21: $275-285$

Martinez-Cummer M. A., Heck R., LeEson S. 2006. Use of axial X-ray microcomputer tomography to assess threedimensional trabecular microarchitecture and bone mineral density in single comb white leghorn hens. Poult. Sci. 85: 706-711.

Poulos P. W. 1978. Tibial dyschondroplasia (osteochondrosis) in the turkey. A morphologic investigation. Acta Radiol. Suppl. 358: 197-227.

Peters T. L., Fulton R. M., Robertson K. D., Orth M.W. 2002. Efect of antibiotics in vitro and in vivo avian cartilage degradation. Avian Dis. 47: 75-86.

SIMSA S., MONSONEGO ORNAN E. 2007. Endochondral ossification process of the turkeys (Meleagris gallopavo) during embryonic and juvenile development. Poult. Sci. 86: 565-571.

Talaty P. N., Katanbaf M. N., Hester P. Y. 2010. Bone mineralization in cock commercial broilers and its relationship to gait score. Poult. Sci. 89: 342-348.

Talaty P. N., KatanbaF M. N,. Hester P. Y. 2009a. Life cycle changes in bone mineralization and bone size traits of commercial broilers. Poult. Sci. 88: 1070-7.

Talaty P. N., KatanbaF M. N., Hester P. Y. 2009b. Variability in bone mineralization among purebred lines of meat-type chickens. Poult. Sci. 88: 1963-1974.

TATARA M. R., PiERZYNOWSKi S. G., MA.JCHER P., KRUPSKI W., BRODZKI A., STUDZIŃSKI T. 2004. Effect of alphaketoglutarate $(\mathrm{AKG})$ on mineralization, morphology and mechanical endurance of femur and tibia in turkey. Bull. Vet. Inst. Puławy. 48: 305-309.

TAtara M. R., Sierant-RożMiej N., KruPski W., MajCHER P., Śliwa E., Kowalik S., STUDZiŃSKi T. 2005. Quantitative computed tomography for the assessment of mineralization of the femur and tibia in turkeys. Medycyna Wet. 61: 225-228. (In Polish).

Tykalowski B., Stenzel T, Koncicki A. 2010. Selected problems related to ossification processes and their disorders in bird. Medycyna Wet. 66: 464-469. (In Polish). 